\title{
THE WYTIGA NEGOTIATION — NATIVE TITLE AND SKILLS TRAINING
}

\author{
MICHAEL WEIR*
}

\section{INTRODUCTION}

The debate as to the appropriate use of skills training in law school has matured to the extent that arguably the question is not whether skills should be taught but how and where skills should be taught. ${ }^{1}$ This note discusses The Wytiga Negotiation, a part of the integrated skills program in the LLB at Bond University School of Law. This note will discuss the procedures followed and the results obtained using a student survey completed immediately after the completion of the exercise. The Wytiga Negotiation The materials for the Wytiga Negotiation ${ }^{2}$ focus on negotiations pursuant to the provisions of the Native Title Act 1993 (Cth) (NTA). The framework for the exercise is the NTA provisions for negotiation between parties to an application for native title.

\section{The Facts}

The Wytiga Negotiation creates a fictional tribe of Aborigines centred around Longreach who have made application for native title over a specified area of land. Attached to the materials is a copy of the NTA statutory application form (Form 1). The focus of the exercise is the resolution of issues between four parties, ie:

- Aborigines — the Wytiga tribe — represented by Traditional Elder William Tamagee

- State Government — represented by Wendy Barber

- Pastoralists - represented by Harry Downtoeart

- Mining Company - Tandarra Limited Represented by Joan Shilton

It was considered important in preparing the materials that no party be in an unassailable position in regard to the primary issues. It was hoped this would enhance incentives for co-operation between parties to achieve individual and joint aims. The following issues arise in regard to the role of each party to the negotiation.

\section{William Tamagee - Traditional Elder of the Wytiga Tribe of Aborigines}

William is concerned to avoid proceeding to a Federal Court hearing because of some uncertainties in regard to the proof of native title.

The Wytiga tribe is not opposed to development as long as they receive proper compensation and their particular sacred sites are preserved from development. William is seeking at least $\$ 100$ million in compensation comprising cash or equivalent.

The primary legal issues that arise for the Wytiga tribe are as follows:

- the effect on native title of the grant of pastoral leases in $1978 .^{3}$

- the impact of the proposed grant of mining leases and their ability to negotiate in that process. ${ }^{4}$

- the evidentiary problems in proving native title on an application for native title.

- the basis for the calculation of compensation for the extinguishment of native title by pastoral leases and proposed mining leases. ${ }^{5}$ 


\section{State Government}

It is concerned with 'the compensation potentially payable in regard to the extinguishment of native title as a result of the grant of crown leaseholds since 1978. The same concern would exist in regard to any proposed mining leases. The state government seeks to limit compensation to $\$ 15$ million in direct government spending. The State government wants to encourage other parties ie the mining company and pastoralists to assist in reducing the compensation payable by giving access to sites, profit sharing on commercial enterprises, and other benefits.

The primary legal issues for the State Government are:

- the basis of calculation of compensation for extinguishment of native title.

- the requirements for negotiations in regard to a 'future act' of granting a mining lease.

\section{Pastoralists}

The pastoralists are in a strong position legally as crown leasehold granted since 1978 would extinguish native title and create a right to compensation in a native title holder. ${ }^{6}$ For this reason the facts provide that the State government has indicated that if large compensation payments are required by it this will be reflected in the crown rental for the pastoral leases. These leases are shortly due for renewal. The pastoralists are unable to pay any compensation owing to their dire financial position. However, they could consider access subject to protection for stock and property. The primary legal issues for the pastoralists are :

- the effect of the grant of pastoral leases upon native title.

- the parameters of negotiations between Aborigines and the State Governments. ${ }^{7}$

\section{Mining Company — Tandarra Ltd}

The mining company wants to commence mining in the area. As a result it is interested in obtaining resolution of the issue to take account of expected improvements in world metal prices. The State government has made it clear that any large compensation payout will be reflected in the royalties payable to the State government.

Tandarra Ltd have indicated they would be prepared to consider a wide range of options to satisfy the requirements of Aborigines as long as the security of tenure which they seek is preserved. They have indicated that any compensation package including cash or other benefits must not exceed \$10 million otherwise the mining operation will be uneconomic.

\section{Selection of Fact Pattern}

Native Title was chosen as the focus of the negotiation for the following reasons:

- The topic is current and is an issue which students should be able to identify with.

- It raises a number of substantive law issues in native title considered in lectures and tutorials.

- It has the potential for students to appreciate the social, political and cultural concerns of the various parties to native title negotiations.

\section{Educational Objectives of the Exercise}

The educational objectives of the negotiation exercise are as follows:

- "To develop the skill of identifying in a multi-party negotiation one's own BATNA, other individual parties interest, to generate options and then to negotiate solutions."

This objective incorporates the content of the negotiation theory dealt with in the introductory lecture material and in reading given prior to the exercise. As development of negotiation skills is the primary focus of the exercise, this objective required some level of precision.

- "to comprehend and apply those provisions of the Native Title Act 1993 (Cth) relevant to an application for native title and negotiation between parties to that application."

- "students will demonstrate the skill of preparing, researching, delivering and negotiating in a team 
allowing all team members to contribute equally.”

- "students should practice presenting argument and speaking in a group setting."

\section{Legal Content}

Objective 2 emphasises the important role taken by the provisions of the Native Title Act in the negotiation. In my view a negotiation exercise in a law subject should have a very clear legal basis. This approach is based upon two concepts:

1 A negotiation or in fact any skills program can enhance and develop an understanding of substantive law. Mack is of the view that:

one of the great strengths of clinical legal education is to help us to understand the unbreakable nexus between substantive law, legal process and lawyer tasks and between theory and practice. ${ }^{8}$

Use of clinical legal education, which includes skills training, can improve student learning of doctrine and analysis of cases and statutes by placing these concepts into their dynamic context while allowing students a more active role in their own learning ${ }^{9}$ Le Brun describes this process as allowing students to "situate" their learning..$^{10}$ Educational research suggests that the process of learning law can be maximised by maintaining a nexus between legal theory and legal practice. ${ }^{11}$

2 If one of the objectives of a law school program is to prepare individuals for the profession, negotiation exercises should be placed in a legal context. Law students should have some understanding of what is legally possible or enforceable between the parties. A lawyer, or any negotiator, can improve the quality of their negotiation if aware of the legal strengths and weaknesses of the client's position and the context in which the negotiation is taking place. This is an essential aspect of the development of a party's BATNA. This objective was included after initial versions of this exercise resulted in a disappointing response from students in relation to their attention to legal aspects.

To enhance attention to this issue, students were provided with a set of questions which they were expected to prepare and be able to answer before, during or after the negotiation exercise.

The performance of students in reacting to particular questions indicated a good level of understanding of the legal background to the negotiation.

\section{PRACTICALITIES - HOW WAS IT DONE?}

\section{When Held?}

The exercise is held in the fourth week of semester during the designated tutorial times over the course of that week. Individual tutorial groups with numbers of 10 to 12 are divided into four sub groups. The responsibility of each subgroup is to prepare a response and to negotiate as one of the four designated parties.

\section{Prenegotiation Stage}

Students are encouraged to have pre-negotiation meetings with other parties to sift through areas of agreement and to isolate the issues requiring negotiation. This activity is important in promoting the role of preparation in successful negotiation while de-emphasising the "performance" at the negotiation. Such preparation can indicate that negotiation is based upon techniques and strategies that can be mastered with preparation and practice. ${ }^{12}$

\section{Materials}

Materials include the following components:

- an explanation of the exercise

- criteria for assessment

- educational objectives

- map of area in question 
- a copy of the relevant Native Title application form.

The materials are handed to the students two weeks before the exercise while each group is given a "confidential" fact sheet which sets out that party's approach to the negotiation.

\section{The Negotiation}

At each negotiation session the four parties negotiate the issues which they consider to be of relevance. No guidance is given to the students as to how the negotiation session should be organised. It has been observed that often the State government provides a chairing role in negotiations between the parties. Students are advised that the focus of the exercise is the process of negotiation. Students are not obliged to reach a final resolution or reaching a final agreement. This avoids pressure to resolve the whole of the issue within the hour.

It is usual to have two staff members in attendance for each session to avoid the perception of subjectivity in marking. Each student is given an individual mark based upon his or her performance pursuant to the stated assessment criteria. A portion of this mark reflects the performance of the group.

\section{Evaluation and Reflection}

The absence of appropriate feedback and reinforcement is seen as one of the major weaknesses of traditional legal education. ${ }^{13}$

The negotiation exercise, which is usually held over a period of 50 to 60 minutes, involves a period of 10 minutes for feedback and reflection. This is an important period for students to receive feedback as to how it is perceived the negotiation proceeded.

The two staff members comment upon the achievement of the objectives of the exercise by each team. Wherever possible feedback is provided to individuals on the strengths of their performance with suggestions for improvement.

Marking is based upon the specified criteria for assessment provided in the materials. One technique often used is for one staff member to note each occasion that a student speaks during the exercise. Notes are also taken when the student has made an insightful comment or has contributed significantly to the exercise. ${ }^{14}$ After the exercise the markers confer on the marks allotted to individual students. An attempt is made to have at least one person (normally the party who gave the lecture on negotiation theory) at most sessions to achieve some level of consistency in marking across the groups.

\section{Survey Results}

So as to assist in assessing the success of the exercise in achieving the educational objectives, immediately after completion of the exercise students were asked to complete an anonymous survey form. The questions were designed to provide a response to the success of the educational objectives. The results of the survey was as follows.

\section{Question 1}

The exercise and my preparation has contributed to my understanding of the legal doctrines at the basis of the Mabo decision and the Native Title Act.

\begin{tabular}{|c|c|c|c|}
\hline not at all & to some extent & substantially & a great deal \\
\hline 1 & 39 & 79 & 29 \\
\hline
\end{tabular}

This result indicates that virtually without exception the students were of the view that the exercise, at least to some extent, contributed to their understanding of the substantive law concepts at the basis of the exercise. Noteworthy is the fact that a vast majority considered the contribution was substantial or better. This could reflect the fact that students:

- were advised that part of their marks could be determined by knowledge of substantive issues 
- had just been lectured on the topic

- were obliged to understand a number of substantive issues to deal with important negotiation points the topic stimulated them sufficiently that they were motivated

- to improve their knowledge of the relevant legal issues

The survey provides evidence that educational objective 2 has, at least in the students' view, been substantially achieved indicating that substantive issues can be taught or reinforced in the process of teaching skills.

\section{Question 2}

The exercise has been an opportunity to develop skills I consider relevant to the practice of law.

\begin{tabular}{|c|c|c|c|c|c|c|}
\hline \multicolumn{2}{|c|}{ not at all } & \multirow{2}{*}{$\begin{array}{c}\text { to some } \\
\text { extent }\end{array}$} & \multicolumn{2}{|c|}{ substantially } & \multicolumn{2}{|c|}{ a great deal } \\
\hline 1 & 2 & & 4 & 5 & 6 & 7 \\
\hline 2 & 1 & 1 & 2 & 49 & 60 & 32 \\
\hline
\end{tabular}

This result emphasises that most students considered the skills learnt in the exercise were relevant to the practice of law. Perhaps the most important aspect of this objective is that students perceive it as a relevant skill. This can only improve the level of attention to the task as well as providing a useful diversion from attention to traditional forms of education. This process emphasised the essential difference between traditional didactic teaching and skills training. The student is not asked to simply discuss the required steps in an application for native title; the student is asked to act as if they are acting on behalf of an applicant. This supports the process of learning by doing. ${ }^{15}$

\section{Question 3}

The exercise has reinforced and enhanced my knowledge and skills in regard to negotiation.

\begin{tabular}{|c|c|c|c|c|c|c|c|}
\hline \multicolumn{2}{|c|}{$\begin{array}{c}\text { strongly } \\
\text { disagree }\end{array}$} & \multicolumn{3}{c|}{ disagree } & \multicolumn{2}{c|}{ agree } & \multicolumn{2}{c|}{$\begin{array}{c}\text { strongly } \\
\text { agree }\end{array}$} \\
\hline 1 & 2 & 3 & 4 & 5 & 6 & 7 \\
\hline 0 & 0 & 0 & 4 & 69 & 57 & 11 \\
\hline
\end{tabular}

There were no students who indicated that the exercise did not reinforce or enhance their knowledge and skills in regard to negotiation. The purpose of this exercise with its time restraints and limitations could not attempt to bring students to the level of expert negotiators. The purpose of the integrated programme is to provide at least "survival" skills. ${ }^{16}$ Roper notes a tendency to expect too much from students when designing negotiation exercises. ${ }^{17}$

Tamsitt perceives the role of negotiation training includes provision of basic skills and to give students the fundamentals of negotiation. ${ }^{18}$ The skills developed in law school should provide at least a starting point for "real world" practice and provide an exposure to the literature at the basis of this endeavour. The experience of practice should provide students with the opportunity to build upon the framework and foundation established in their undergraduate negotiation training. ${ }^{19}$ Galanter has stated that "skills exercises do not presume to make students expert negotiators any more than the torts course aims to make them personal injury specialists; they are there to provide a sense of the elements, the parameters, the possibilities." 20

\section{Question 4}

The exercise has allowed me to appreciate the concerns of parties likely to be involved in negotiations on native title issues. 


\begin{tabular}{|c|c|c|c|c|c|c|}
\hline \multicolumn{2}{|c|}{$\begin{array}{l}\text { strongly } \\
\text { disagree }\end{array}$} & disagree & \multicolumn{2}{|c|}{ agree } & \multicolumn{2}{|c|}{$\begin{array}{l}\text { strongly } \\
\text { agree }\end{array}$} \\
\hline 1 & 2 & 3 & 4 & 5 & 6 & 7 \\
\hline 1 & 1 & 1 & 7 & 59 & 59 & 26 \\
\hline
\end{tabular}

This response reveals that most students considered they were provided with the opportunity to appreciate the concerns of the parties. This has the potential of providing context within which the substantive law is taught. It is easier to remember and understand the various issues relevant to the proof of native title if one had been exposed to or been involved in a negotiation on a matter relevant to native title. The facts required students to be sensitive to the economic, social and spiritual concerns of the parties to the negotiation. As a model of principled negotiation is promoted, insensitivity to those issues would have derailed negotiations to the detriment of the student's result.

\section{Question 5}

The exercise has allowed me to recognise in practice types of behaviours and tactics that hinder and enhance successful negotiation.

\begin{tabular}{|c|c|c|c|c|c|c|c|}
\hline \multicolumn{2}{|c|}{$\begin{array}{c}\text { strongly } \\
\text { disagree }\end{array}$} & \multicolumn{3}{c|}{ disagree } & \multicolumn{2}{c|}{ agree } & \multicolumn{2}{c|}{$\begin{array}{c}\text { strongly } \\
\text { agree }\end{array}$} \\
\hline 1 & 2 & 3 & 4 & 5 & 6 & 7 \\
\hline 1 & 0 & 3 & 34 & 60 & 31 & 16 \\
\hline
\end{tabular}

This question asks students to assess the role of the exercise in allowing them to identify obstacles to good negotiation. This question raises the issue of the ability of students to not only practice good negotiation skills but to identify the influences upon the process. This indicates an ability to analyse the group dynamics of a negotiation which indicates a higher level skill may have been achieved in this exercise. As this is the last exercise in the integrated programme, it is a hopeful sign this ability should have started to emerge at this stage of the degree.

\section{Question 6}

The exercise has provided the opportunity to practice effective cooperation between members of a group.

\begin{tabular}{|l|c|c|c|c|c|c|c|}
\hline \multicolumn{2}{|c|}{$\begin{array}{c}\text { strongly } \\
\text { disagree }\end{array}$} & \multicolumn{3}{c|}{ disagree } & \multicolumn{2}{c|}{ agree } & \multicolumn{2}{c|}{$\begin{array}{c}\text { strongly } \\
\text { agree }\end{array}$} \\
\hline 1 & 2 & 3 & 4 & 5 & 6 & 7 \\
\hline 0 & 1 & 5 & 37 & 42 & 40 & 15 \\
\hline
\end{tabular}

The positive response to this question is an indication of a learning outcome that may not be the primary focus of the exercise. This is a factor in the assessment criteria and is dealt with in educational objective 3.

The life of a law student often involves a solitary journey where reward is determined solely by one's own individual effort. ${ }^{21}$ This does not reflect "real world experience where working within a group towards a common goal is often required. It appears that a majority of students are in agreement that some learning of skills occurred in this exercise. The use of group work can on a more individual basis assist in providing a more conducive environment in the classroom as bonds are forged between members of the class ${ }^{22}$ while $^{23}$ providing a change from the normally teacher centred learning practiced in most law schools. ${ }^{23}$ The negative responses might indicate that some groups were small (only 2 individuals) where group dynamics were not crucial or where there was concern as to the equality of effort by all members of the group towards the group enterprise. 


\section{Question 7}

The exercise has provided good training in the skill of oral presentation.

\begin{tabular}{|c|c|c|c|c|c|c|c|}
\hline \multicolumn{2}{|c|}{$\begin{array}{c}\text { strongly } \\
\text { disagree }\end{array}$} & \multicolumn{3}{c|}{ disagree } & \multicolumn{2}{c|}{ agree } & \multicolumn{2}{c|}{$\begin{array}{c}\text { strongly } \\
\text { agree }\end{array}$} \\
\hline 1 & 2 & 3 & 4 & 5 & 6 & 7 \\
\hline 1 & 1 & 5 & 36 & 45 & 30 & 15 \\
\hline
\end{tabular}

This is a skill dealt with in tutorials, moots and in the negotiation exercise. The attention to this aspect is clearly relevant as the role of a professional will often involve attention to the advocacy role. The negative feedback by some students could reflect the difficulty in obtaining sufficient time for each individual student in the time allotted for the exercise. A discussion of this concern is found below.

\section{Summary of Results}

Generally the educational objectives of the exercise have been achieved. Probably most importantly the survey has indicated that many other learning outcomes have been achieved other than merely negotiation training and substantive law inculcation.

\section{General Comments}

Students were asked to make general comments. Most comments were positive. However, some were critical of a number of points:

a. lack of time to negotiate. This is clearly a problem when you have about 12 students attempting to contribute within a period of 45 minutes, ie an average of approximately 4 minutes per student. The only way to deal with this issue is to reduce the size of the group or to extend the period of negotiation beyond the usual tutorial period. Both of these solutions have resource implications and/or require staff to provide time outside standard teaching time.

b. That on occasions some students dominate unfairly. This is a problem of both lack of time and group dynamics. Many students indicated that patience was one virtue that they were forced to practice in the exercise. The marking criteria include reference to the need to include all students in the discussion. Some instructors on occasions have asked a student to desist from further comment if they have dominated to the exclusion of other students, to allow others to contribute.

\section{CONCLUSION}

The role of law schools in skills training is now well established. The question is how to provide that training to students. Few would doubt that the role of undergraduate education should avoid overemphasis on skills training to the detriment of traditional educational goals. It is suggested that the Wytiga Negotiation indicates that students can receive valuable training in negotiation which reinforces and enriches substantive law concepts. The use of carefully contrived educational objectives can assist the process of learning by focussing educators and students upon the purpose and goals of the exercise.

* Faculty of Law, Bond University. (C)1997. (1996) 7 Legal Educ Rev 253.

1 M Le Brun, \& R Johnstone, The Quiet (R)evolution: Improving Student Learning in Law (Sydney: Law Book Company Limited, 1994) 169-170.

2 Copy of materials available from author at request.

3 Native Title Act 1993 (Cth) ss 14, 15, 21, 31, 33, 72, 229 [referred to as NTA]. The provisions of the Commonwealth legislation were used as the basis of the exercise as the relevant Queensland legislation, Native Title Act 1993 (Qld) was not at that time enacted and the NTA is the basis of the substantive law lecture.

4 NTA ss 21,26.

5 NTA s51.

6 NTA ss $14,15,17$.

7 NTA ss 71, 79.

8 K Mack, Bringing Clinical Learning into a Conventional Classroom (1993) 4 Legal Educ Rev 89, at 106. 
9 Id at 90 .

10 Le Brun and Johnstone, supra note 1, at 170.

11 A Leaver, Contextualising Law: An Attempt to Operationalise Theory by Teaching Interviewing in the Law School (1994) 5 Legal Educ Rev 195, at 196, nn 4-5.

12 Roper C, An Approach to Teaching Lawyers Negotiations (1983) 1 J Prof L Educ 51, at 53.

13 Mack, supra note 8, at 107 and J McFarlane, \& P Boyle, Instructional Design and Student Learning in Professional Legal Education (1993) 4 Legal Educ Rev 63, at 67.

14 Tamsitt took the view that feedback and reinforcements could have four attributes: “(1) it should be specific, not vague (2) it should be made as quickly as possible after the behaviour (3) it should be direct (4) positive reinforcement is to be preferred to negative reinforcement” G Tamsitt, Teaching Interviewing Negotiating: the impossible dream (1983) 1 J Prof Legal Educ 59 , at 65.

15 Mack, supra note 8, at 90.

16 K Lauchland, Skills for the Masses — From the Cradle to the Grave, paper presented to the 1992 ALTA Conference, 11 July 1992 , at 3.

17 Roper, supra note 12, at 52.

18 Tamsitt, supra note 14 , at 61 .

19 Roper, supra note 12, at 57.

20 M Galanter, Worlds of Deals: Using Negotiation to Teach about Legal Process (1984) 34 J Legal Educ 271.

21 L Boulle, Undergraduate Education of Practical Skills, paper presented at "Producing the Compleat Lawyer" Conference at Bond University, 13 February 1991, 10.

22 McFarlan, \& Boyle, supra note 13, at 87.

23 J Goldring, Academic and Practical Legal Education: Where Next? An Academic Lawyers Response to Noel Jackling and Neil Gold (1987) 5 J Prof Legal Educ 105, at 111. 